http:/ / e-journal.adpgmiindonesia.com/index.php/jmie

JMIE: Journal of Madrasah Ibtidaiyah Education, 5(1), 2021, 67-77

\title{
SOCIAL EMOTIONAL LEARNING PROGRAM FOR BUILD RESPONSIBLE CHARACTER OF STUDENTS IN ELEMENTARY SCHOOL
}

\author{
Lu'lu'a Farah Adiba'), Asep Ediana Latip') \\ Syarif Hidayatullah State Islamic University Jakarta \\ E-mail: lulufarahadiba@gmail.com²),asep.ediana@uinjkt.ac.id²)
}

Submit: 4 Agustus 2020, Revisi: 20 April 2021, Approve:19 Mei 2021

\begin{abstract}
The aim of this research was describe Social Emotional Learning (SEL) Program for build responsible character of students in elementary school. The approach for this study was qualitative. The main method of this study was library research that supported with filed research. Library research that referred in this study was an activity to collected data, read, took notes, and processed the data that related with Social Emotional Program in Schools. It was obtained from books, journals, and articles. There are 5 main journals supported by 10 other. The researcher was collected the data from documents, research notes, and interviews. The interviewees are people who have direct contact with Social Emotional Program such as Head of Social Emotional Program Department, teachers, students and parents of Kharisma Bangsa Elementary School. This study used purposive sampling technique. The instruments of this research were document check list, notes, and interview guidelines. Data analysis was achieved through a content analysis technique. The result showed that Social Emotional Learning Program can build responsible character of students in elementary school. It can be obtained by growing social awareness, self-management, self-awareness, responsible decision making, and relationship skills after implementing Social Emotional Learning Program. The Social Emotional Learning Program was effective to build the responsibility by using some approaches there were Explicit SEL Instruction, Teacher Instructional, and Integrated with curriculum areas that supported by several strategies between PATH, RC, 4R's, and RULER.
\end{abstract}

Keywords: Social Emotional Learning, Responsible Character, Library Research

Pengutipan: Lu’lu'a Farah Adiba \& Asep Ediana Latip. (2021). Social Emotional Learning Program for Build Responsible Character of Students in Elementary School. JMIE: Journal of Madrasah Ibtidaiyah Education, 5(1), 2021, 67-77. jmie.v5i1.228.

Permalink/DOI: http://dx.doi.org/10.32934/jmie.v5i1.228 


\section{INTRODUCTION}

Character education is very important for students. It will use for their life principal. Nowadays we can see that the world keeps changing and the challenges will be more complicated. Today we know that the information comes so fast meanwhile we have to make sure that is true or not, good or not good, acceptable or not acceptable. In this situation schools as educational institutions have to make sure that their students can accept the challenges from this $21^{\text {st }}$ century era. All of the education facilities should be adapted for preparing students to face the next revolution. (Greenstein, 2012).

This characters education actually mandate on The Indonesian Presidential decree No. 87 in 2017. One of those character values is responsibility (Indonesian Presidential Decree about Strengthening Character Education Number 87 of 2017). Responsibility is the obligation to accept the duty that has it own consequences (Yaumi: 2014). Therefore the character of responsibility becomes very important to be taught from an early age and it given the benefits for a lifetime. When the value of responsibility of students begins to fade, various problems will arise. One of them is the lack of disciplinary action students such as ignoring the teacher's orders and aggressions. Actions of aggressions that occur can be in the form of verbal or physical. Verbal aggression includes insulting, taunting, threatening, and yelling. While physical aggression are like hitting, pushing, kicking, and so on. (Onukwufor, 2013).

Otherwise Mario Piacentini said that based on his research according to PISA data 2015, the countries that have joined to Organization for Economic Co-Operation and Development (OECD) they got 4\% students who reported that they got hitting or pushing and $8 \%$ reported that they are the victim of bad rumors. These cases are going to influence student's performance becomes worse than in schools with lower levels of bullying. In addition, $42 \%$ from 54 countries in this study showed that the bullying can decrease academic achievement. (Safinatunnajah et al., 2018).

Furthermore, the result from the study by Mudroch University in 2017 with 1.000 participants in Australia there were students between 8-9 years old showed that student who has behavioral disorders in the form of raging and fighting left behind for 12 months in academic achievement (Taylor, 2020). In Indonesia there was a viral video in 2019 that showed student cussing the teacher it was happened at Surabaya District. Another case about lack of the responsibility happened in the one of elementary school at Kudus District, Middle Java, in 2017. There was a student got hitting by nine others students in the classroom. (Akbar, 2020).

Consider to those cases, responsibility can be uses as a tool to avoid students miss behavior. When students realize who they really are then they will act as a good student. Based on their moral developmental tasks elementary schools students really need guidance so that tasks can be achieve. The guidance also can be a strong foundation on their future to be a good person. Responsibility also related to social and emotional competencies. Students can apply responsibilities properly accordance with their social and emotional skills. (Alzahrani et al., 2019). Social skills help students to get in touch with the circumstances and the people around them. (Tadjer et al., 2018). In the other hands emotional skills help students to 
receiving, processing, and releasing their emotions. (Cristian \& Anca, 2018). At the end students can make a responsible decision. However, most of the schools more focus on student's academic achievement while they really need guidance to understand more about their emotional and social skills.

Based on interview data that conducted with head of Social-Emotional Learning Program Kharisma Bangsa Elementary School Pondok Cabe, Tangerang Selatan District some of student's behavior that is contrary to the responsibility occurred in this school. Such as verbal aggression is like students cut off teacher talk, shout, and say harshly. In addition physical aggressions also occurred in this school such as pushing the peers. In this case students not respect other as one of duties for being responsible student. Some students also did not submit their assignment punctually. Other data that obtained from the interview is they are using Social-Emotional Learning (SEL) Program to give the learners an understanding about social and emotional aspect that must be understood by students so that they can be responsible learners.

Elias in Bloodworth, 2007 was described SEL as process through which we learn to recognize and manage emotions, care about others, make good decision, behave ethically and responsibly, develop positive relationships, and avoid negative behaviors. (Bloodworth, 2007). From that opinion we can see that SEL is a process that can be learned. Other definition came from Greenberg. He defined SEL as developmentally and culturally appropriate classroom instruction and application of learning to everyday situation, SEL programming builds children's skills to recognize and manage their emotions, appreciate the perspectives of others, establish positive goals, make responsible decisions, and handle interpersonal situation. Basically Greenberg explained that SEL can be implemented by class instructions to develop positive goals, responsible decisions, and handle interpersonal situation. (Merrel, 2010). Furthermore Peterson defined SEL as that is focused on developing student behavior that is socially acceptable as well as understanding and controlling emotions. (Peterson \& Peterson, 2018). In brief Social Emotional is the process to improve the social and emotional skills of students by creating positive environment and directing students to positive goals so students can organized themselves well, making responsible decision, and understands the environment well.

According to The Collaborative of Social and Emotional Learning (CASEL) SocialEmotional Learning has five competencies they are social awareness, self-management, selfawareness, responsible decision making, and relationship skills (CASEL: 2013). In Payton's study he quoted Greenberg opinion that explained SEL was proven to bring a positive influence on students. SEL can prevent problems that occur during the development of students. In this case, SEL also promotes positive habits for students, positive mental health, and as a preparation to become responsible adults. So they can learn better to make a responsible decision. Based on the research results of students who participated in the SEL program showed improvements in aspects of personal, social, and academic life. SEL can also overcome student's emotional problems, stresses, and academic performance so the. (Payton et al., 2008). SEL in promoting responsibility take part as a fundamental. The responsibility of the students will be encouraged by the five competencies of Social Emotional Leraning. 


\section{METHODS}

The methods of this research were Library Research and Field Research. The main method that applied in this research was Library Research which is done with these following steps; 1) selecting a topic; 2) exploring information; 3) forming a focus; 4) collecting information; 5) preparing to present; 6) assessing the process (Kuhltau, 2002). There were 5 main journals or articles and supported by 10 other that analyzed by the researcher. Here are the five main joournals: 1) Agnes S.K. Wong, Cecilia. W. P. Li-Tsang, Andrew. M. H. Siu, Department of Rehabilitation Sciences, The Hong Kong Polytechnic University. "Effect of a Social Emotional Learning Programme for Primary School Students” ; 2) Yehui Wang, Zhaoxi Yang, Yingbin Zhang, Faming Wang, Tour Liu, Tao Xin, Beijing Normal University, China. "The Effect of Social Emotional Competence on Child Development in Western China" ; 3) Esmaeil Sadri Damirchi, Hacettepe University, Ankara, Turki. Penelitian ini berjudul "The Impact of SocialEmotional Learning Skills Programs on Social Development Among Primary School Students” ; 4) M. Alzahrani, M. Alharibi, A. Alodwani. The Effect of Social-Emotional Competence on Children Academic Achievement and Behavioral Development; 5) A. Peterson. Connecting STEM Curriculum with Social Emotional Leraning in Eraly Childhood.

Field research in this study was supported the main method, it was implemented by interviews. The interviews was conducted with Head of Social Emotional Learning Department, 1 homeroom teacher grade 6, 3 students, and 3 parents at Kharisma Bangsa Elementary School, Pondok Cabe, Tangerang Selatan District. Sampling technique has done with purposive sampling. In this technique the criteria of sample have been selected by the researcher so that those sample are relevant to the research question that are being posed. (Emma Bell et al., 2018). Data collection technique of this study was qualitative, that obtained from documents, research notes, and interviews. (Sugiyono: 2017). The instruments of this research were document check list, notes, and interview guidelines. The data was analyzed by content analysis technique. It was done through selecting, comparing, and combining the data to find the relevancy (Krippendorff, 2004).

\section{RESULTS AND DISCUSSION}

The findings of the analysis showed that five competencies in Social-Emotional Learning Program can shape the students responsibilities in elementary schools. Those competencies are social awareness, self-management, self-awareness, responsible decision making, and relationship skills. The five competencies are equipped with various indicators that support the formation of the character of responsibility in various dimensions. Those indicators can be reference for teachers and help to guide the teachers in shaping the responsibility character of students. Here are the descriptions for those five competencies to build the responsible character of elementary school students: 


\section{Self-Awareness to Build Character of Responsibility}

Self-awareness and responsibility involved the connection between personal and social behavior. Self-awareness represents the capacity to identifies, processes, and stores information about the self. There are five effects of self-awareness; escaping the self, increased emotional intensity, self-knowledge, self-regulation and theory of mind. (Morin, 2017). Students need self-fulfillment that is based on realistic self-awareness. By developing students self-awareness it can give effect to their own thinking and understanding of the same information as others. (Flavian, 2018).Self-awareness must be nurtured in the life of society to grow a better future life for students. The importance of self-awareness for students such us prevailing norms in society, awakening human beings, harmonizing social life, and overcome social problems. In the end students are expected to make a responsible decision by develop their self-awareness. (Matitaputty et al., 2018)

Self-awareness also can encourage students to take responsibility through recognize themselves. Students are encouraged to recognize their emotions, attitudes, and behavior as individuals. In addition students are also directed to recognize feelings can arise, and know the impact of these feelings on others. This Self-awareness competency has five indicators; a) Identifying emotions, students are directed to recognize various emotions such as sadness, anger, disappointment, and through someone's facial expressions; b) Self-perception, this indicator directs students to be able to perceive themselves as their strengths, weaknesses, selfconfidence, and the ability to overcome the problems; c) Recognizing Strengths, this indicator encourages students to be aware with their strengths, so that they can developed optimally; d) Self-Confidence, it helps student to shape their confidence. When students realize their strengths then self-confidence will be formed; e) Self-Efficacy, this indicator encourage students to believe in their ability to overcome the situations. It makes students not hesitate in making responsible decisions (CASEL: 2013).

\section{Self-Management to Build Character of Responsibility}

Self-management refers to methods, skills, and strategies by which individuals can actively direct their own activities toward the achievement of objectives, and includes goal setting, decision making, focusing, planning, scheduling, task tracking, self-evaluation, selfintervention, and self-development. Self-management also related to the emotional condition of an individual. Unmanaged emotional reaction that might be happen in students can create psychological condition that inhibit learning and potentially increase the risk of disease later in life. (Ncama, 2011).

Self-management encourages students to be responsible for managing themselves to achieve goals. This relates to the way individuals to manage themselves in order to create individuals who match expectations. When students are taught to be responsible by managing themselves personal well-being will be achieved from orderly self-regulation. This is the basis for students to achieve their goals as a student. This competency define by five indicators there are; a) Impulse Control, this indicator is about emotion and behavior control; b) Stress Management; this indicator directs students to be able to control themselves when facing 
pressure; c) Self Discipline; this indicator can encourage the students to be responsible by being discipline in managing themselves to achieve goals d) Self-Motivation; this indicator can use to forming the students to motivate themselves so that students can be more independence; e) Goal Setting; this indicator can help students to create goals that have a positive influence on him; f) Organizational Skills; This indicator supports students to have ability to organize all things that can help achieve their goals as a good student (CASEL: 2013).

\section{Social Awareness to Build Character of Responsibility}

Social awareness can be defined as the ability to take perspective of and empathize with someone else and to appreciate and respect diversity. Furthermore social awareness is knowledge of what going on in society. Responsibility as a goal of education plays important role. Social awareness can be the one of the ways to build students responsibility. By growing social awareness students will practice their empathy. They can put them-selves in other shoes. So then students can make a responsible decision to act. (Suffari et al., 2019)

This competency encourages students to be responsible for their social environment by empathizing and sympathizing with others. In this case students are directed to understand various norms that apply in the social environment. This competency also directs students to take the perspectives of others from various backgrounds and cultures, so this will teach students to always be open minded. With this social awareness competency, students will also learn to be able to behave in an adaptive and flexible manner depending on the circumstances of the surrounding environment. This competency define by four indicators they are; a) Perspective Taking, this indicator directs students to look at problems through a variety of perspectives so students can be more careful in taking steps; b) Empathy, it is use to directs students to be emphatic. Students are taught to try to understand the situation of others by imagining if they are in someone else's shoes; c) Appreciating diversity, this indicator taught students to be able to appreciate all forms of difference. For example differences regarding race, ethnicity, and culture. With this indicator students can train themselves to always be tolerant as a form of sense of responsibility to the social environment; d) Respect Others; this indicator can use as a tool to teach students to be respect others like respect others decision and others perspective (CASEL: 2013).

\section{Relationships skills to Build Character of Responsibility}

This competency direct students to take responsibility for creating positive relationships. The goal of this competency are learners can build and plan healthy relationships. In addition, with this competency, students can be responsible in negotiating constructive relationships. This competency divides into four indicators; a) Communication, it is the way students communicate that can influence the formation of relationships; b) Social Involvement, this indicator encourages students to be responsible for making good ties with their social environment; c) Building Relationships, it can be used to guide students in forming positive 
and beneficial relationships; d) Teamwork, this indicator directs students to have good work skills in the group (CASEL, 2013).

\section{Responsible Decision Making to Build Character of Responsibility}

This competency directs students to make responsible decisions consider to ethical standards, safety issues, and social norms. This competency can encourage students to make constructive decisions by identifying, clarifying, and evaluating situations. This competency divides into five indicators; a) Identifying The Problems; it is provides knowledge so that students can understand the problem well. When they understand how to recognize and solve problems with good behavior, disciplinary actions can be reduced; b) Analyzing Situations, this indicator directs students to analyze problems from various point of view; including how and why problems can arise; c) Problem Solving, it can be used as an exercise for students to be able to practice and develop methods for solving problems. Here students need to identify possible choices to make and explore the potential consequences of each choice; d) Evaluating and Reflecting, when students can take time to evaluate their success in identifying, analyzing, and solving a problem then they can develop their skills. Such reflection can make the steps that need to be taken in in deciding something at the next opportunity; e) Ethical Responsibility; it can train students to identify the consequences of each decision, students must also consider the moral aspects that they feel need to be done (CASEL: 2013).

Based on those explanations above we know that the five competencies of SocialEmotional Learning Program can be used as reference and measurement in forming the character of responsibility. It is help teachers to shape the responsibilities of students. The teacher's steps can be more directed by these competencies. In addition, teachers can view students more objective, also with indicators the assessment can be more measured. Students with high social and emotional competency tended to do more self-regulation and make responsible decisions and also it gives them knowledge about the meaning of deeper learning that related to the sense of responsibility of a student. (Wang et al., 2019). When students are aware with the meaning of learning that is the tasks of students, they will feel more responsible for academics. Students can maintain their interest in learning something and ultimately will improve academic achievement which is the fruit of the character responsibility. Furthermore, other study explained that social awareness strongly relate with responsible decision making. When someone wants to make a decision that is accordance with the existing, they should consider others from various perspectives such as emotions, hobbies, needs, and desires. When an individual can make the right decision that are not offensive and do not hurt others. The more someone understands the situations of others, the more responsible the will be in making decisions.

Based on the interviews, Kharisma Bangsa Elementary School had been implementing The Social-Emotional Program start from January 2019. The implementation for this program is carried out in all classes form grade one to grade six for about $2 \times 35$ minutes. This school made collaboration with Sanford Harmony. The cooperation includes procurement of books, training, and provision of learning steps. In this school Social-Emotional Learning Program is 
considered to help teachers as a preventive measure to against student's miss behavior. Especially for students in lower grade who have communication bloopers like shouting and interrupting other people in a wrong way. Other problem is they have not been able to control their emotions in the first semester. They do not understand yet about how to receive, regulate, and express their emotions properly. After The Social-Emotional Program was implemented for a semester it is rise positive effect. They begin to learn how the way to communicate with others, socialize, and regulate their emotions. Those statements supported by study that explained Social-Emotional Learning Program can decrease the problems of miss behavior. (Wong et al., 2014). In the other hand one of the study described that SocialEmotional Learning Program also affected to social skills development of students in elementary school. (Damirchi, 2013).

Other facts that obtained from the interview was the benefit of Social-Emotional Learning Program can be felt in lower grade. Meanwhile for students in high class the effect is still not visible. Social-Emotional Learning Program approved to forming the character of responsibility. Apart from competence, the learning steps also listed in the manual book. The activities that written in the book provide students to be more active and it support students to learn social and emotional learning in the classroom. Students are directed to actively participate in the learning process. It will train students to take responsibility by actively participating. Then along with the learning process the character of the responsibility will be formed. In addition, because all the steps in implementing Social-Emotional Learning Program have been written in the manual book it is very helpful, so that the implementation will be measured and directed. This program also implemented in the family. Students and their family do some activities like help each-others, make food for charity programs and also some games that need good cooperation with other family member.

To implement The Social-Emotional Learning Program certainly requires some approaches that need to be done. Those following approaches are here (CASEL: 2013); 1) Explicit SEL Instruction, this approach involves the teacher in creating instructions related to SEL topics that support the formation of responsibility such as emotional labeling; 2) Instructional Teacher, the teachers can be involved in creating classroom experience to develop skills in the SEL Program; 3) Integrated with Academic Curriculum Areas, this approach is another alternative that implemented by integrating the basic components of SEL in the academic curriculum.

There are also strategies that can be used in teaching those five competencies of SEL (CASEL: 2013); 1) Promoting Alternative Thinking Strategy (PATH) which aims to improve social and emotional competence of students such as prevent violence, aggression, and other problems. This Strategy refers to affective, behavioral, cognitive, dynamic (ABCD) which believes that social competence can be achieved if the affective and cognitive competencies of students can work together; 2) The Responsive Classroom Approach (RC Approach), this strategy combines social, emotional, and academic need for students. This strategy seeks to balance learning with safe, challenging, and fun classroom conditions; 3) The Reading, Writing, Respect and Resolution Strategy (4Rs), this strategy trains teachers to use a literacybased curriculum. The teacher can integrate The Social-Emotional Learning Program in 
classroom such as problem solving, cultural differences, cooperative attitudes and cooperation; 4) Recognizing, Understanding, Labeling, Expressing and Regulating (RULER), this strategy is a strategy with emotional literacy that includes recognizing, understanding, labeling, expressing, and regulating emotions. So at the end students are expected to master in RULER skills.

\section{CONCLUSION}

Based on the results of the study it can be concluded that The Social Emotional Learning Program can build the character of the responsibilities of students in elementary schools. This can be obtained by growing social awareness, self-management, self-awareness, responsible decision making, and relationship skills after implementing The Social Emotional Learning Program. The Social Emotional Learning Program is effective by using some approaches there were Explicit SEL Instruction, Teacher Instructional, and Integrated with Curriculum Areas that supported by several strategies between PATH, RC, 4R's, and RULER. The five competencies in the implementation of The Social Emotional Learning Program encouraging students to always be responsible in various ways as follows; 1) self-awareness encouraging students to be responsible for their feelings and the impact of their feelings on others; 2) self- management, encouraging students to be responsible in terms of self-regulation in order to achieve the goals; 3) social awareness, encouraging students to be responsible on their social environment by being empathetic, sympathetic, flexible, and adaptive; 4) relationships skills, encouraging students to be responsible for creating healthy and beneficial relationships; 5) responsible decision making, encouraging students to be responsible for making decision according to social and moral norms.

\section{REFERENCES}

\section{Scientific Journals and Articles}

Alzahrani, M., Alharbi, M., \& Alodwani, A. (2019). The Effect of Social-Emotional Competence on Children Academic Achievement and Behavioral Development. International Education Studies, 12(12), 141. https://doi.org/10.5539/ies.v12n12p141

Bloodworth, M. R. (2007). The Scientific Base Linking Social and Emotional Learning to School Success The Foundations of Social and Emotional Learning. July. https://doi.org/10.1080/10474410701413145

Cristian, S., \& Anca, S. (2018). The importance of social and emotional development of primary school children in the learning process of literacy skills The importance of social and emotional development of primary school children in the learning process of literacy skills. May 2019.

Damirchi, E. S. (2013). The Impact of Social-Emotional Learning Skills Programs on Social Development Among Primary School Students. 4(16), 202-207.

Flavian, H. (2018). students self-awareness development Towards teaching and beyond: Strengthening education by understanding students, self-awareness development. January 2016. https://doi.org/10.1177/1757743815624118 
Matitaputty, S., Hastuti, R., Christie, A., \& Rahutami, I. (2018). Outdoor Learning: Fostering Social Awareness with Community Service. SHS Web of Conferences, 59, 01026. https://doi.org/10.1051/shsconf/20185901026

Morin, A. (2017). Self - Awareness Part 1: Definition, Measures, Effects, Functions, and SelfAwareness Part 1: Definition, Measures, Effects, Functions, and Antecedents. October. https://doi.org/10.1111/j.1751-9004.2011.00387.x

Ncama, B. P. (2011). Self, self-care and self-management concepts: implications for self-management education. January.

Onukwufor, J. N. (2013). Physical and Verbal Aggression Among Adolescent Secondary School Students in Rivers State of Nigeria. 1(2), 62-73.

Payton, J., Weissberg, R. P., Durlak, J. A., Dymnicki, A. B., Taylor, R. D., Schellinger, K. B., \& Pachan, M. (2008). The Positive Impact of Social and Emotional Learning for Kindergarten to Eighth-Grade Students: Technical Report - Findings from Three Scientific Reviews. Collaborative for Academic, Social, and Emotional Learning (CASEL), December, 12. http://www.lpfch.org/sel/casel-narrative.pdf

Peterson, A., \& Peterson, A. (2018). Connecting STEM Curriculum with Social Emotional Learning in Early Childhood Learning in Early Childhood. 22.

Suffari, N. F., Zain, M., Majid, M., Afiq, M. D., \& Tazilah, K. (2019). a Conceptual Study of Social Responsibility Awareness and Practices Among School. 1(1), 1-17.

Tadjer, H., Lafifi, Y., Derindere, M., Gulsecen, S., \& Seridi-Bouchelaghem, H. (2018). What are The Important Social Skills of Students in Higher Education? Preface of the Editors, October 2020, 128.

Wang, Y., Yang, Z., Zhang, Y., Wang, F., Liu, T., \& Xin, T. (2019). The effect of socialemotional competency on child development in western China. Frontiers in Psychology, 10(JUN). https://doi.org/10.3389/fpsyg.2019.01282

Wong, A. S. K., Li-Tsang, C. W. P., \& Siu, A. M. H. (2014). Effect of a social emotional learning programme for primary school students. Hong Kong Journal of Occupational Therapy, 24(2), 56-63. https://doi.org/10.1016/j.hkjot.2014.11.001

Bell. Emma. (2018). Business Research Method. United Kingdom: Oxford University Press.

Domitrovich Celene. Durlak Joe. Goren Paul. Weissberg Roger. (2013). Emotional Learning Programs, Preschool and Elementary School Edition. Chicago: The Collaborative of Social and Emotional Learnng (CASEL).

Greenstein, Laura. (2012). Assessing 21st Century Skills: A Guide to Evaluation Mastery and Authentic Learning. California: Conwin

Indonesian Presidential Decree about Strengthening Chracter Education No. 87 in 2017.

Kuhltau, C. C. (2002). Teaching The Library Research. USA: Scarecrow Press Inc.

Krippendorff, K. (2004). Content analysis: an introduction to its methodology. New York: Sage Publication. 
Payton John. at al. (2008). The Positive Impact of Social and Emotional Learning for Kindergarten to Eight-Grade Students: Findings from Three Scientific Reviews. Chicago, IL: Collaborative for Academic, Social, and Emotional Learning. Chicago: CASEL.

Yaumi, M. (2014). Landasan, Pilar, dan Implementasi. Jakarta: Prenadamedia Group.

Sugiyono. 2017. Metode Penelitian Kuantitaif, Kualitatif, dan RひD. Bandung: Alfabeta.

Safinatunnajah. Rahmawati. (2018). Bullying and Student Achievement Trend Analysis of PIS A 20122015 Results. Proceeding Book of $1^{\text {st }}$ International Conference Education Assessment and Policy. 1 (55-60).

www.abc.net.au

www.cnnindonesia.com 